\title{
Seasonal influenza vaccines induced high levels of neutralizing cross-reactive antibody responses against different genetic group influenza $\mathrm{A}(\mathrm{H} 1 \mathrm{~N} 1) \mathrm{pdm} 09$ viruses
}

\author{
Anu Haveri ${ }^{\mathrm{a}, *}$, Niina Ikonen ${ }^{\mathrm{a}}$, Anu Kantele ${ }^{\mathrm{b}}$, Veli-Jukka Anttila ${ }^{\mathrm{b}}$, Eeva Ruotsalainen ${ }^{\mathrm{b}}$, \\ Carita Savolainen-Kopra ${ }^{\mathrm{a}}$, Ilkka Julkunen ${ }^{\mathrm{a}, \mathrm{c}}$ \\ ${ }^{a}$ Expert Microbiology Unit, Department of Health Security, National Institute for Health and Welfare (THL), POB 30, 00271 Helsinki, Finland \\ ${ }^{\mathrm{b}}$ Division of Infectious Diseases, Inflammation Center, University of Helsinki and Helsinki University Hospital, POB 348,00029 HUS Helsinki, Finland \\ ${ }^{\mathrm{c}}$ Institute of Biomedicine, University of Turku and Turku University Hospital, Kiinamyllynkatu 10, 20520 Turku, Finland
}

\section{A R T I C L E I N F O}

\section{Article history:}

Received 3 January 2019

Received in revised form 25 March 2019

Accepted 31 March 2019

Available online $\mathrm{xxxx}$

\section{Keywords:}

Antibodies

Microneutralization test

Humoral immunity

Influenza A

Pandemic

Vaccine

\begin{abstract}
A B S T R A C T
Influenza $\mathrm{A}(\mathrm{H} 1 \mathrm{~N} 1) \mathrm{pdm} 09$ viruses have been circulating throughout the world since the 2009 pandemic. A/California/07/2009 (H1N1) virus was included in seasonal influenza vaccines for seven years altogether, providing a great opportunity to analyse vaccine-induced immunity in relation to the postpandemic evolution of the A(H1N1)pdm09 virus. Serum antibodies against various epidemic strains of influenza A (H1N1)pdm09 viruses were measured among health care workers (HCWs) by haemagglutination inhibition and microneutralization tests before and after 2010 and 2012 seasonal influenza vaccinations. We detected high responses of vaccine-induced neutralizing antibodies to six distinct genetic groups. Our results indicate antigenic similarity between vaccine and circulating $A(H 1 N 1) p d m 09$ strains, and substantial vaccine-induced immunity against circulating epidemic viruses.
\end{abstract}

(c) 2019 Published by Elsevier Ltd.

\section{Introduction}

Since the 2009 pandemic, influenza A(H1N1)pdm09 viruses have been circulating throughout the world, evolving continuously $[1,2]$. To date, eight genetic groups and several subgroups have been identified in $\mathrm{A}(\mathrm{H} 1 \mathrm{~N} 1)$ pdm09 viruses [3]. Analyses using panels of post-infection ferret antisera showed $A(H 1 N 1) p d m 09$ viruses to be antigenically similar for relatively long time periods. Therefore, $\mathrm{A} /$ California/7/2009 vaccine virus was recommended as the seasonal influenza vaccine $\mathrm{A}(\mathrm{H} 1 \mathrm{~N} 1)$ strain for the Northern hemisphere until the epidemic season 2016-2017 [4].

The haemagglutination inhibition (HI) test is the most commonly used method for measuring antibody levels against influenza viruses, while the microneutralization (MN) test, which is also widely employed, has certain advantages over the HI test [5]. Measurable anti-influenza antibodies detected by the HI test have been shown to correlate well with protective immunity [6]. In general, $\mathrm{HI}$ and $\mathrm{MN}$ antibody titres correlate [7], although the MN assays appear to have a greater sensitivity [8-10]. Good

\footnotetext{
* Corresponding author.

E-mail address: anu.haveri@thl.fi (A. Haveri).
}

correlation has been shown between the results of different MN assays [11], yet the ELISA-based neutralization assays tend to show lower variation [12].

There has been a great deal of research on the immunogenicity of the $\mathrm{A}(\mathrm{H} 1 \mathrm{~N} 1) \mathrm{pdm} 09$ vaccine virus, which has mostly concentrated on analysing immune responses against the vaccine virus itself [13-24]. However, limited amount of data is available on vaccine-induced neutralizing antibody responses towards a wider range of wild type epidemic $\mathrm{A}(\mathrm{H} 1 \mathrm{~N} 1)$ pdm09 viruses. For the present study we collected sera from health care workers (HCWs) before and after influenza vaccinations in 2010 and 2012. In the present study we analysed vaccine-induced humoral immune responses by $\mathrm{HI}$ and $\mathrm{MN}$ tests against viruses belonging to six genetic subgroups of influenza $\mathrm{A}(\mathrm{H} 1 \mathrm{~N} 1) \mathrm{pdm} 09$ virus. In addition, we analysed the differences in immune responses induced by two different vaccine preparations.

\section{Materials and methods}

\subsection{Vaccines}

The seasonal influenza vaccines administered in this study were Fluarix $^{\mathrm{TM}}$ (GlaxoSmithKlein, lot number AFLUA523AA) in 2010 and 
Vaxigrip $^{\circledR}$ (Sanofi Pasteur MSD, lot numbers J8389-2 and J8395-2) in 2012. Both vaccines were non-adjuvanted and contained the three WHO-recommended influenza virus strains. The participants were vaccinated in a national vaccination campaign. Different vaccines were used in different years due to a government funded National Vaccination Programme that provided seasonal influenza vaccines free to health care workers, young children, elderly and medical risk groups according to national vaccination policy. Vaccines were administered intramuscularly (deltoid muscle) and one vaccine dose was given to each person. Serum samples were collected prior to vaccination on day 0 , and the postvaccination serum specimens were collected on day 21 .

\subsection{Participants}

Clinically healthy HCWs were recruited on a voluntary basis from the staff of the Department of Medicine at Helsinki University Hospital and the Virology Unit at the National Institute for Health and Welfare. Eight men and 42 women, median age 47 years (range: 19-64), were involved in the Fluarix ${ }^{\mathrm{TM}}$ vaccination trial in 2010. Two years later, at the time of the Vaxigrip ${ }^{\circledR}$ vaccination in 2012, eight men and 42 women, median age 46 years (range: $24-65$ ), participated in the study. 23 of the participants were included in both vaccination studies. All participants gave their informed written consent before enrolment in the study.

\subsection{Viruses}

Representative viruses from six genetic groups of influenza A (H1N1)pdm09 viruses that circulated in Finland during 20092013 [25,26] were selected for serological analyses: A/Finland/ 554/2009 (group 1), A/Finland/24/2010 (group 3), A/Finland/124/ 2011 (group 4), A/Finland/153/2011 (group 5), A/Finland/148/2011 (group 7), A/Finland/142/2011 (group 6A), A/Finland/300/2012 (group 7), A/Finland/308/2013 (group 6C). Additionally, the A/California/07/2009 (group 1) vaccine virus was included in the analyses. The clinical samples for isolation of the viruses included in this study have been collected for routine viral diagnostic purposes. Based on national laws, ethical permission was not required for specific microbiological diagnostics and further characterisation of detected viruses. All viruses were propagated in MDCK cells and stored in aliquots at $-70^{\circ} \mathrm{C}$.

\subsection{Phylogenetic and structural analyses of the HA molecule}

The phylogenetic analysis of the HA gene for selected Finnish viruses and reference strains was performed as described [25]. Mega (Molecular Evolutionary Genetics Analysis) software version 5 [27] was used in amino acid sequence comparison and the construction of the phylogenetic tree. The Neighbour-joining method [28] with the maximum composite likelihood model [29] was used to generate the phylogenetic tree. Bootstrapping was performed with 1000 replicates [30]. Reference virus sequences for the phylogenetic tree were obtained from GISAID EpiFlu ${ }^{\mathrm{TM}}$ Database.

The three-dimensional structure of the HA molecule of the influenza $\mathrm{A}(\mathrm{H} 1 \mathrm{~N} 1)$ pdm09 virus, A/California/04/2009 (RCSB Protein Bank accession number 3LZG) was used to locate amino acid differences between the epidemic Finnish A(H1N1)pdm09 viruses (seasons 2009-2010, 2010-2011 and 2012-2013) and the A/California/07/2009 vaccine virus. The molecular models were constructed using RasMol Molecular Graphics software version 2.7.3 [31]. Amino acid residues in the HA molecule were numbered without the signal peptide sequence.

\subsection{Serologic assays}

Antibody levels were measured in serum specimens collected before the vaccination (day 0 ) and 21 days after the vaccination with seasonal influenza vaccines Fluarix (2010) or Vaxigrip (2012).

Serum specimens were assayed by the haemagglutination inhibition (HI) test against the virus strains described above. The HI tests were performed according to WHO guidelines [32] using turkey erythrocytes $(0.5 \% / \mathrm{vol})$. For statistical analyses, serum specimens with $\mathrm{HI}$ titers $<10$ were assigned a titer value of 5 .

Microneutralization (MN) tests were performed with the virus strains described above (excluding A/Finland/554/2009 due to low amounts of serum specimens). The MN test was done according to the WHO guidelines [32]. We optimized the MN tests for the particular viruses and antibodies used in this study.

In the MN test two-fold serial dilutions of heat inactivated sera were performed in $50 \mu \mathrm{l}$ volumes of the diluent $\left(\right.$ OptiPro $^{\mathrm{TM}} \mathrm{SFM}$, Gibco, supplemented with $0.2 \%$ BSA, non-essential amino acids and Penicillin-Streptomycin) in 96-well tissue culture plates. Serum dilutions were mixed with diluent containing 100 TCID $_{50}$ of different influenza viruses. Control wells with the virus and the diluent (VC), the diluent alone (CC) and an internal positive control were included in each plate. After incubation for $1 \mathrm{~h}$ at $37{ }^{\circ} \mathrm{C}$ with $5 \% \mathrm{CO}_{2}, 2.5 \times 10^{4}$ MDCK cells were added to each well for an $18-20 \mathrm{~h}$ incubation at $37{ }^{\circ} \mathrm{C}$ with $5 \% \mathrm{CO}_{2}$. Wells were fixed within cold $80 \%$ acetone for $10 \mathrm{~min}$.

The presence of influenza antigens in fixed cells was detected by enzyme-linked immunosorbent assay (ELISA). The fixed plates were washed with washing buffer (PBS, 0.05\% Tween 20). An inhouse rabbit antibody against the whole virus (A/California/07/2009 whole virion vaccine antigen, GSK) [26] was used as the primary antibody. The antibody was diluted 1:4000 in PBS containing $5 \%$ milk. $80 \mu \mathrm{l}$ of antibody dilution was added and incubated at room temperature for $1 \mathrm{~h}$ followed by washing with washing buffer (see above). Subsequently, $80 \mu \mathrm{l}$ of 1:2000 dilution of polyclonal horseradish peroxidase-labeled goat anti-rabbit immunoglobulins (Dako, Denmark) was added to each well and incubated at room temperature for $1 \mathrm{~h}$ followed by washing as above. Freshly prepared substrate o-phenylenediamine dihydrochloride $(100 \mu \mathrm{l})$ (Sigma-Aldrich, USA) was added into each well and incubated at room temperature. The reaction was stopped after 20 min with $100 \mu \mathrm{l} 1 \mathrm{M}$ sulfuric acid. Absorbances were measured at $492 \mathrm{~nm}$ and $620 \mathrm{~nm}$. The neutralizing endpoint was determined as previously described [32]. For statistical analyses, serum specimens with MN titers $<10$ and greater than 1280 were assigned a titer value of 5 and 2560, respectively.

\subsection{Statistical analysis}

Geometric mean titers (GMT) with 95\% confidence intervals and seroprotection rates (HI titer $\geq 1: 40$, MN titer $\geq 1: 160$ ) for each virus were calculated. Statistical differences between the groups were calculated using Student's $t$-test (paired, two-tailed) and the statistically significance level of difference was set to $p<0.01$.

$\mathrm{HI}$ and MN assays were correlated and compared with Pearson and t-tests. Log-transformed titers were performed by linear regression analysis using Microsoft Excel 2010 software.

\section{Results}

The epidemic $\mathrm{A}(\mathrm{H} 1 \mathrm{~N} 1) \mathrm{pdm} 09$ viruses used in this study were collected between the years 2009 and 2013 from sentinel sites of influenza surveillance network (garrisons and health care centres for general public) and non-sentinel sites (clinical microbiology laboratories) situating in different geographic regions in Finland. 
The studied strains clustered in six genetic groups (Fig. 1). The number of amino acid substitutions increased during the evolution of the HA gene (Table 1) and the changes occurring on the surface of the HA molecule compared to the A/California/07/2009 virus (vaccine virus) are illustrated in Fig. 2.

Using vaccine virus A/California/07/2009 as a reference strain, we found that the antibody titers of the $\mathrm{HI}$ and $\mathrm{MN}$ assays correlated strongly positively $\left(n=190, \quad r=0.6287, \quad R^{2}=0.8215\right.$, $\mathrm{p}<0.0001$ ). A HI titer of 40 was considered to be equivalent to a MN titer of 160 (Fig. 3).

Geometric mean titers (GMTs) obtained with the MN test were typically higher than those seen in the HI test (Table 2). Preexisting $\mathrm{A}(\mathrm{H} 1 \mathrm{~N} 1)$ pdm09 antibody titres did not differ statistically significantly between the groups of 2010 and 2012. Three weeks after Fluarix and Vaxigrip vaccinations, GMTs for both assays and for all studied viruses increased significantly $\mathrm{p}<0.01$ $\mathrm{p}<0.0001$, respectively.

Vaccine-induced anti-H1N1pdm09 antibody GMTs were somewhat higher after administration of the Fluarix vaccine compared to that seen in response to Vaxigrip vaccination (Table 2). As analysed by the HI test Fluarix vaccine induced antibody responses between the prevaccine and postvaccine serum specimens increased 3.2 to 5.4 -fold depending on the virus strain. In the Vaxigrip group the corresponding increases were 2.0 to 2.5-fold for different viruses (Fig. 2a). The GMTs for Fluarix and Vaxigrip vaccine induced antibody rises measured by the MN test ranged from 4.9 to 7.4 and from 2.4 to 2.8 , respectively (Fig. 2b). It is noteworthy that the basal levels (day 0) of anti-H1N1pdm09 antibodies were somewhat higher in the Vaxigrip vaccine group and thus the fold increase remained at a lower level as compared to that seen in the Fluarix group. However, in all cases the postvaccination (day 21) GMTs were higher in the Fluarix group as compared to the Vaxigrip group (Fig. 2a and b).

Next we analyzed the rate of seroprotection i.e. the percentage of individuals showing $\geq 1: 40$ titer in the $\mathrm{HI}$ test and $\geq 1: 160$ titer in the MN test, before and after influenza vaccination. Seroprotection rates (SRs) as measured by HI and MN tests,

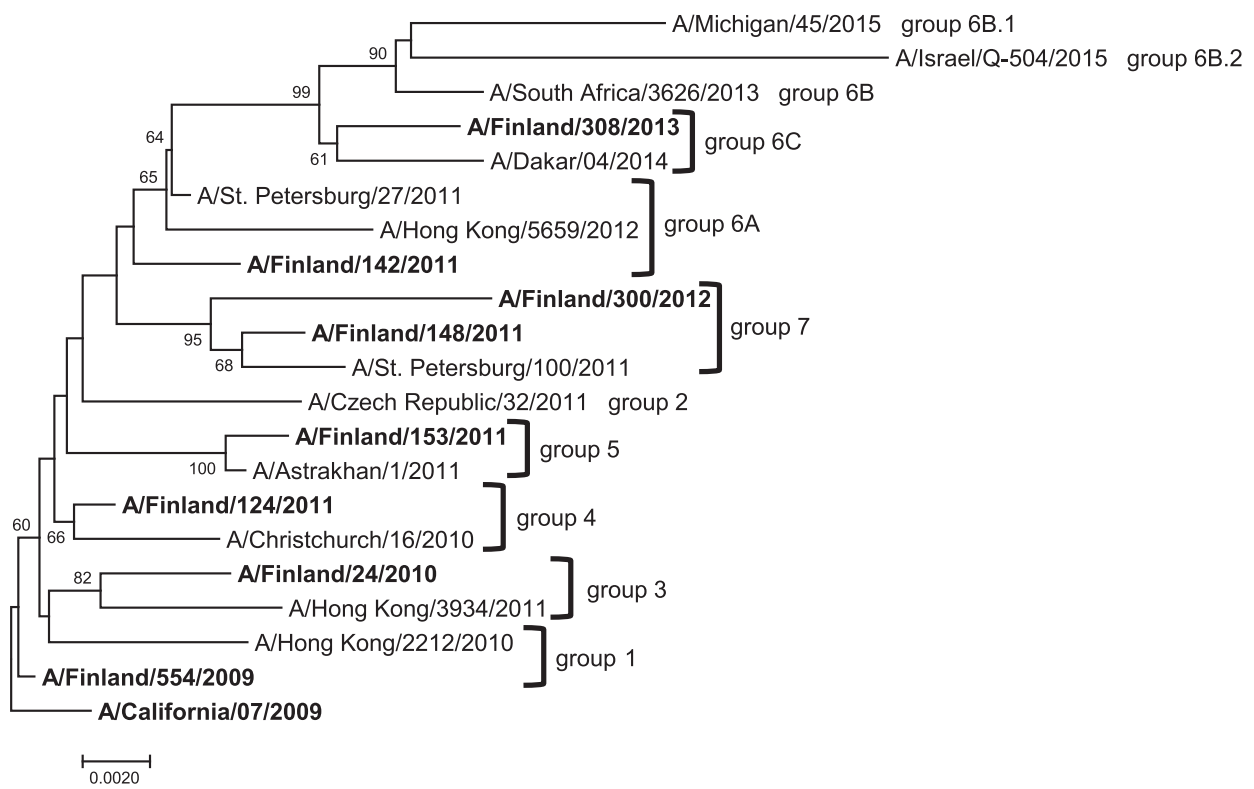

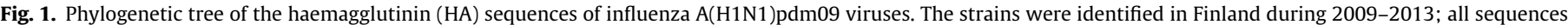

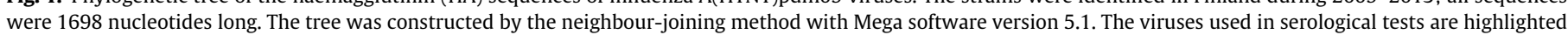

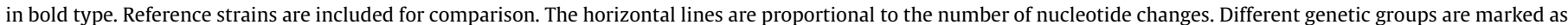
numbers.

Table 1

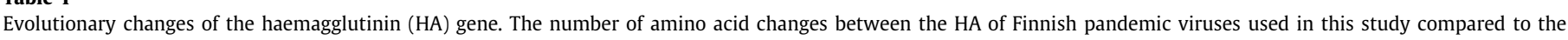
vaccine strain A/California/07/2009.

\begin{tabular}{|c|c|c|c|c|c|c|c|c|}
\hline \multirow[t]{2}{*}{ Virus strain } & \multirow{2}{*}{$\begin{array}{l}\text { Genetic } \\
\text { group }\end{array}$} & \multirow{2}{*}{$\begin{array}{l}\text { Number of } \\
\text { changes }\end{array}$} & \multicolumn{5}{|c|}{ Antigenic sites } & \multirow[t]{2}{*}{ Other sites } \\
\hline & & & Sa & $\mathrm{Sb}$ & $\mathrm{Cb}$ & Ca1 & $\mathrm{Ca} 2$ & \\
\hline A/California/07/2009 & 1 & & & & & & & \\
\hline A/Finland/554/2009 & 1 & 3 & & & & & & P83S, I321V, S451N \\
\hline A/Finland/24/2010 & 3 & 6 & & & & S203T & & P83S, A134T, S183P, I321V, N441K \\
\hline A/Finland/124/2011 & 4 & 5 & N125D & & & S203T & & P83S, I321V, E374K \\
\hline A/Finland/153/2011 & 5 & 8 & & & & $\begin{array}{l}\text { S203T, } \\
\text { R205K }\end{array}$ & & P83S, D97N, I216V, V249L, I321V, E274K \\
\hline A/Finland/148/2011 & 7 & 8 & & S185T & & S203T & & P83S, S143G, A197T, I321V, E374K, S451N \\
\hline A/Finland/142/2011 & $6 \mathrm{~A}$ & 9 & & S185T & & S203T & & N56S, P83S, D97N, I321V, E356G, E374K, S451N \\
\hline A/Finland/300/2012 & 7 & 11 & $\mathrm{~K} 160 \mathrm{~N}^{*}$ & S185T & & S203T & & $\begin{array}{l}\text { P83S, A197T, I216M, I321V, E374K, S451N, I460T, } \\
\text { E499K }\end{array}$ \\
\hline A/Finland/308/2013 & $6 C$ & 13 & & $\begin{array}{l}\text { S185T, } \\
\text { A186T }\end{array}$ & $\mathrm{T} 72 \mathrm{~A}$ & S203T & & $\begin{array}{l}\text { P83S, D97N, V173I, V234I, K283E, I321V, E374K, } \\
\text { S451N, E499K }\end{array}$ \\
\hline
\end{tabular}

Potential glycosylation site NLS (160-162). 

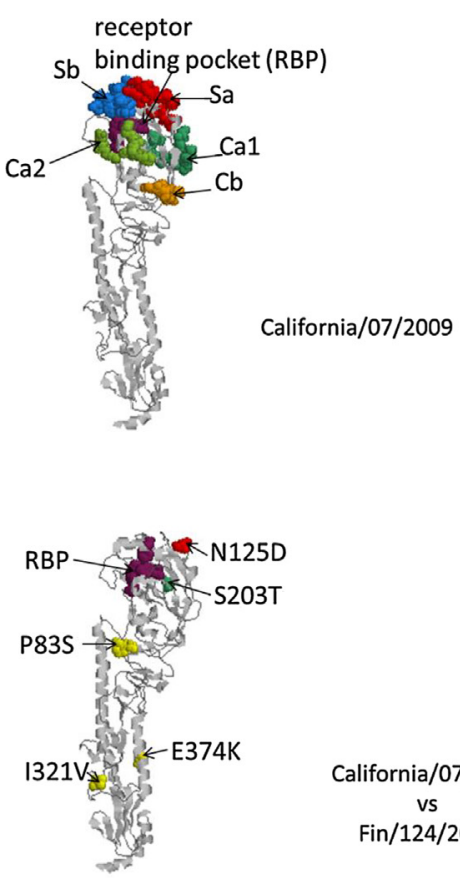

California/07/2009 vs Fin/124/2011

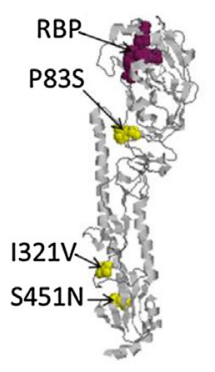

California/07/2009 vs Fin/554/2009

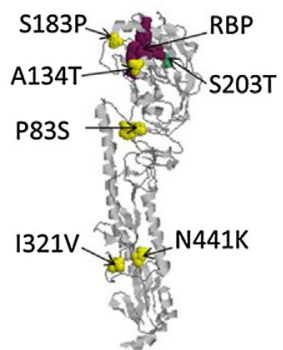

California/07/2009 vs Fin/24/2010
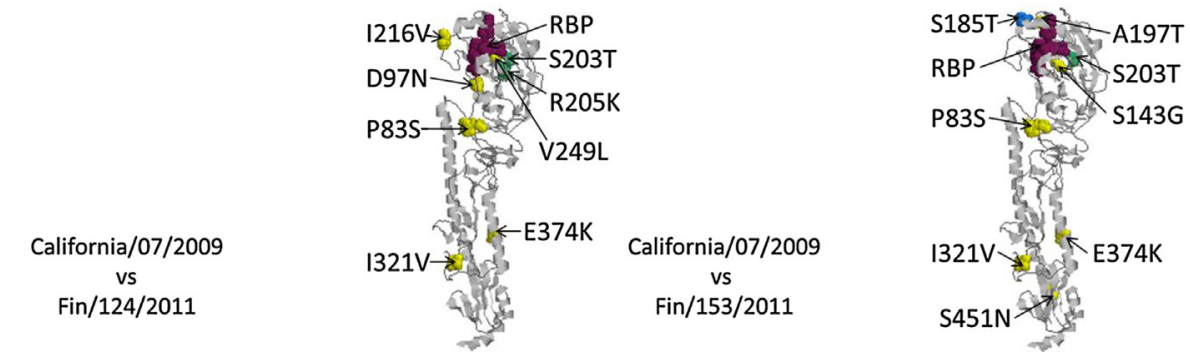

California/07/2009 vs Fin/148/2011
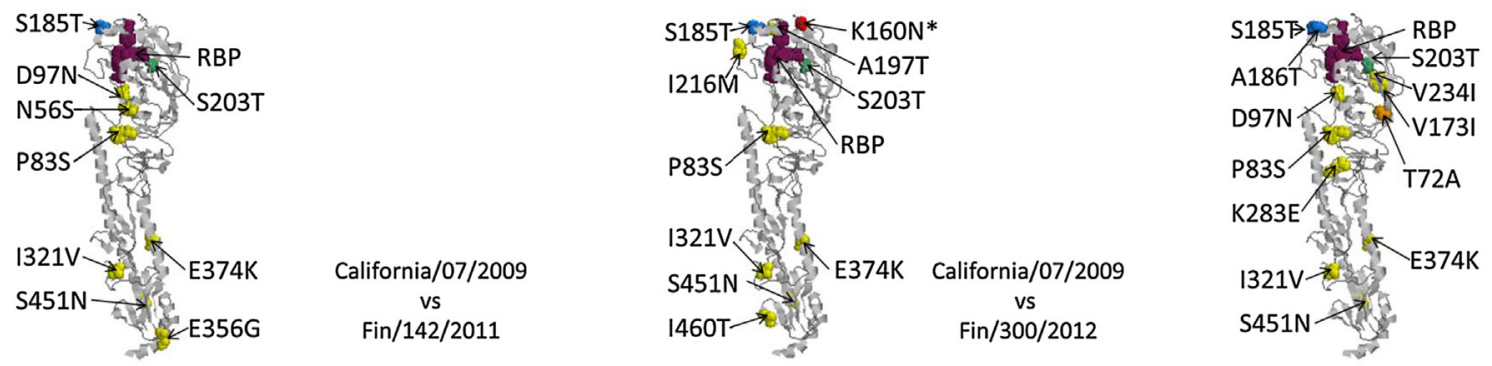
California/07/2009 Fin/308/2013

Fig. 2. Schematic representation of amino acid differences in the HA molecule between the Finnish influenza $A(H 1 N 1) p d m 09$ viruses and the vaccine virus, $A / C a l i f o r n i a / 07 /$ 2009. On the upper left, a side view of the monomeric structure of HA molecule of influenza A(H1N1)pdm09 (A/California/04/2009; RCSB Protein Bank accession number 3LZG) with previously identified H1 protein-specific antigenic sites (Sa in red, Sb in blue, $\mathrm{Ca} 1$ in darker green, $\mathrm{Ca} 2$ in lighter green and $\mathrm{Cb}$ in orange) of influenza $\mathrm{A}(\mathrm{H} 1 \mathrm{~N} 1$ ) viruses and with the receptor binding pocket (RBP, purple) is shown. The amino acid changes in Finnish A(H1N1)pdm09 viruses compared to A/California/07/2009, the vaccine strain, are illustrated in the monomeric HA structure and coloured as in the A/California/07/2009 structure. Amino acid changes outside the antigenic sites are shown in yellow. Changes are illustrated by amino acid residue numbers and with a serial number of the virus where the respective amino acid change has been observed. ${ }^{*}$ potential glycosylation site NLS (160-162). (For interpretation of the references to colour in this figure legend, the reader is referred to the web version of this article.)

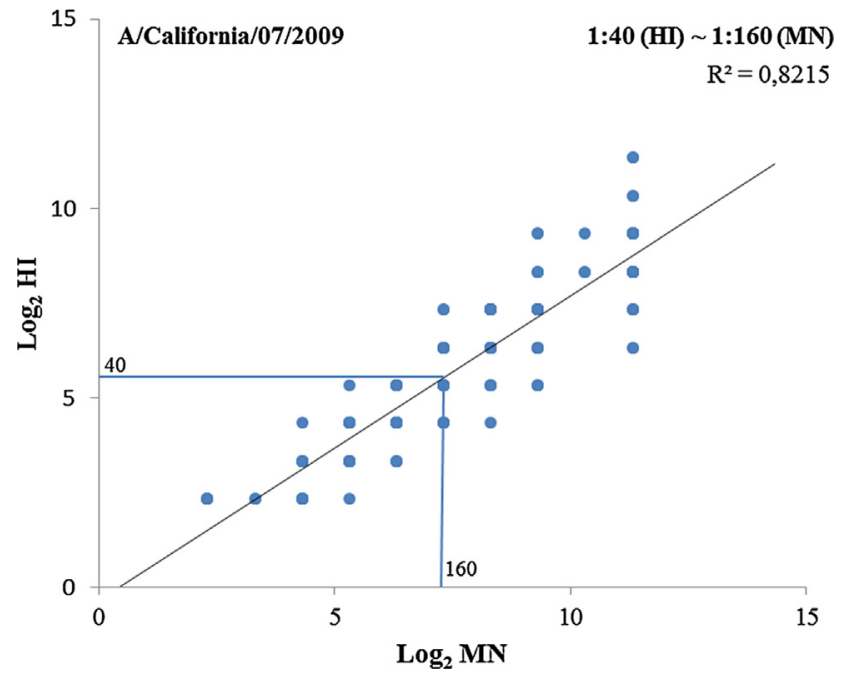

Fig. 3. Correlation of the antibody titres to A/California/07/2009 measured by haemagglutination inhibition ( $\mathrm{HI}$ ) and microneutralization (MN) tests. Log-transformed $\mathrm{HI}$ and $\mathrm{MN}$ titres are presented, trend line and coefficient of determination calculated by linear regression analysis. Each dot may include the value from several serum specimens. Total number of serum specimens is 190. were almost equally high in both vaccine groups and both vaccines induced SRs that were well over $70 \%$ that is considered as the rate for an efficient vaccination. However, somewhat higher SR values were obtained by the MN test (Fig. 4). Preexisting SR values were higher in 2012 compared to those seen in the 2010 vaccine group. SRs before 2010 and 2012 vaccinations varied $32.7-49.0 \%$ and $30.0-64.0 \%$ in the $\mathrm{HI}$ test and $34.0-52.0 \%$ and $44.0-56.0 \%$ in the MN test, respectively. Both vaccinations induced very high SRs. HI SRs ranged from 75.5$89.8 \%$ to $74.0-84.0 \%$ and MN SRs ranged from $82.0-94.0 \%$ to 78.0-86.0\% for different virus strains after Fluarix 2010 and Vaxigrip 2012 vaccinations, respectively.

Correlation coefficients ( $r$ ) of antibody levels between $\mathrm{A} / \mathrm{Califor}$ nia/07/2009 vaccine virus and epidemic $A(H 1 N 1) p d m 09$ viruses are shown in Table 3. Significant correlation $(p<0.0001)$ between all virus strains was seen. There was, logically, a tendency for the correlation coefficient to be higher between the viruses that were genetically and structurally more closely related with the vaccine virus and each other. Correlation of A/California/07/2009 and selected epidemic strain-specific antibody responses are shown (Fig. 5). 
Table 2a

Vaccine-induced humoral immune responses against different influenza A(H1N1)pdm09 viral strains measured by haemagglutination inhibition (HI) test.

\begin{tabular}{|c|c|c|c|c|c|c|c|c|c|}
\hline Virus strain (genetic group) & $\begin{array}{l}\text { A/California/ } \\
07 / 2009 \text { (1) }\end{array}$ & $\begin{array}{l}\text { A/Finland/ } \\
554 / 2009 \text { (1) }\end{array}$ & $\begin{array}{l}\text { A/Finland/ } \\
24 / 2010 \text { (3) }\end{array}$ & $\begin{array}{l}\text { A/Finland/ } \\
124 / 2011 \text { (4) }\end{array}$ & $\begin{array}{l}\text { A/Finland/ } \\
153 / 2011 \text { (5) }\end{array}$ & $\begin{array}{l}\text { A/Finland/ } \\
142 / 2011 \\
(6 \mathrm{~A})\end{array}$ & $\begin{array}{l}\text { A/Finland/ } \\
308 / 2013 \\
(6 C)\end{array}$ & $\begin{array}{l}\text { A/Finland/ } \\
148 / 2011 \text { (7) }\end{array}$ & $\begin{array}{l}\text { A/Finland/ } \\
300 / 2012 \text { (7) }\end{array}$ \\
\hline \multicolumn{10}{|l|}{$\begin{array}{l}\text { Geometric mean titer }[95 \% \mathrm{Cl}] \\
\text { Fluarix vaccine } 2010^{\#}\end{array}$} \\
\hline Day $0(n=49)$ & $\begin{array}{l}30.1 \\
{[20.4-44.4]}\end{array}$ & $\begin{array}{l}22.1 \\
{[14.8-32.9]}\end{array}$ & $\begin{array}{l}20.3 \\
{[14.2-28.9]}\end{array}$ & $\begin{array}{l}20.0 \\
{[14.3-28.0]}\end{array}$ & $\begin{array}{l}26.5 \\
{[18.4-38.3]}\end{array}$ & $\begin{array}{l}19.4 \\
{[13.9-27.3]}\end{array}$ & $\begin{array}{l}22.4 \\
{[15.7-31.9]}\end{array}$ & $\begin{array}{l}23.4 \\
{[16.6-32.9]}\end{array}$ & $\begin{array}{l}33.3 \\
{[23.0-48.1]}\end{array}$ \\
\hline Day $21(n=46-49)$ & $\begin{array}{l}162.4^{* * *} \\
{[110.2-239.5]}\end{array}$ & $\begin{array}{l}116.6^{* * *} \\
{[79.2-171.6]}\end{array}$ & $\begin{array}{l}74.5^{* * *} \\
{[55.7-99.8]}\end{array}$ & $\begin{array}{l}81.1^{* * *} \\
{[59.9-109.9]}\end{array}$ & $\begin{array}{l}112.3^{* * *} \\
{[83.9-150.4]}\end{array}$ & $\begin{array}{l}62.9^{* * *} \\
{[47.1-84.1]}\end{array}$ & $\begin{array}{l}73.5^{* * *} \\
{[53.1-101.8]}\end{array}$ & $\begin{array}{l}87.1^{* * *} \\
{[66.8-113.5]}\end{array}$ & $\begin{array}{l}135.0^{* * *} \\
{[98.7-184.7]}\end{array}$ \\
\hline Fold increase & 5.4 & 5.3 & 3.7 & 4.1 & 4.2 & 3.2 & 3.3 & 3.7 & 4.1 \\
\hline Vaxigrip vaccine $2012^{\mathrm{a}}$ & & & & & & & & & \\
\hline Day $0(n=50)$ & $\begin{array}{l}35.8 \\
{[25.9-49.5]}\end{array}$ & $\begin{array}{l}27.9 \\
{[20.0-38.9]}\end{array}$ & $\begin{array}{l}23.0 \\
{[17.1-30.9]}\end{array}$ & $\begin{array}{l}24.3 \\
{[17.9-32.9]}\end{array}$ & $\begin{array}{l}32.5 \\
{[24.0-43.9]}\end{array}$ & $\begin{array}{l}21.1 \\
{[15.9-28.2]}\end{array}$ & $\begin{array}{l}24.6 \\
{[18.5-32.9]}\end{array}$ & $\begin{array}{l}30.7 \\
{[22.8-41.5]}\end{array}$ & $\begin{array}{l}36.8 \\
{[26.7-50.8]}\end{array}$ \\
\hline Day $21(n=50)$ & $\begin{array}{l}81.1^{* *} \\
{[60.0-109.7]}\end{array}$ & $\begin{array}{l}66.0^{* *} \\
{[48.9-88.8]}\end{array}$ & $\begin{array}{l}54.3^{* * *} \\
{[41.6-70.8]}\end{array}$ & $\begin{array}{l}55.0^{* *} \\
{[41.3-73.2]}\end{array}$ & $\begin{array}{l}80.0^{* * *} \\
{[60.5-105.8]}\end{array}$ & $\begin{array}{l}46.6^{* *} \\
{[35.0-62.0]}\end{array}$ & $\begin{array}{l}48.6^{*} \\
{[37.1-63.6]}\end{array}$ & $\begin{array}{l}67.7^{* *} \\
{[51.3-89.5]}\end{array}$ & $\begin{array}{l}85.7^{* *} \\
{[65.1-112.9]}\end{array}$ \\
\hline Fold increase & 2.3 & 2.4 & 2.4 & 2.3 & 2.5 & 2.2 & 2.0 & 2.2 & 2.3 \\
\hline
\end{tabular}

The significance of differences (increase) between day 0 and day 21 geometric mean titres ${ }^{*} \mathrm{p}<0.01^{* *} \mathrm{p}<0.0011^{* * *} \mathrm{p}<0.0001$.

\# One dose of non-adjuvanted trivalent seasonal influenza vaccine Fluarix ${ }^{\circledR}$ produced by GSK Biologicals was given in 2010.

a One dose of non-adjuvanted trivalent seasonal influenza vaccine Vaxigrip ${ }^{\circledR}$ produced by Sanofi Pasteur was given in 2012.

Table 2b

Vaccine-induced humoral immune responses against different influenza A(H1N1)pdm09 viral strains measured by microneutralization (MN) test.

\begin{tabular}{|c|c|c|c|c|c|c|c|c|}
\hline $\begin{array}{l}\text { Virus strain } \\
\text { (genetic group) }\end{array}$ & $\begin{array}{l}\text { A/California/07/ } \\
2009 \text { (1) }\end{array}$ & $\begin{array}{l}\text { A/Finland/24/ } \\
2010(3)\end{array}$ & $\begin{array}{l}\text { A/Finland/124/ } \\
2011(4)\end{array}$ & $\begin{array}{l}\text { A/Finland/153/ } \\
2011(5)\end{array}$ & $\begin{array}{l}\text { A/Finland/142/ } \\
2011(6 \mathrm{~A})\end{array}$ & $\begin{array}{l}\text { A/Finland/308/ } \\
2013(6 C)\end{array}$ & $\begin{array}{l}\text { A/Finland/148/ } \\
2011(7)\end{array}$ & $\begin{array}{l}\text { A/Finland/300/ } \\
2012(7)\end{array}$ \\
\hline \multicolumn{9}{|c|}{$\begin{array}{l}\text { Geometric mean titer }[95 \% \mathrm{Cl}] \\
\quad \text { Fluarix vaccine } 2010^{\#}\end{array}$} \\
\hline Day $0(n=50)$ & $\begin{array}{l}94.5 \\
{[60.5-147.5]}\end{array}$ & $\begin{array}{l}82.2 \\
{[48.7-138.7]}\end{array}$ & $\begin{array}{l}86.9 \\
{[55.9-135.3]}\end{array}$ & $\begin{array}{l}83.4 \\
{[51.8-134.2]}\end{array}$ & $\begin{array}{l}113.1 \\
{[67.6-189.4]}\end{array}$ & $\begin{array}{l}85.7 \\
{[53.4-137.5]}\end{array}$ & $\begin{array}{l}139.3 \\
{[91.2-212.7]}\end{array}$ & $\begin{array}{l}107.0 \\
{[67.0-171.1]}\end{array}$ \\
\hline Day $21(n=50)$ & $\begin{array}{l}667.2^{* * *} \\
{[472.1-942.9]}\end{array}$ & $\begin{array}{l}498.7^{* * *} \\
{[343.8-723.2]}\end{array}$ & $\begin{array}{l}622.5^{* * *} \\
{[439.0-882.7]}\end{array}$ & $\begin{array}{l}613.9^{* * *} \\
{[435.4-865.7]}\end{array}$ & $\begin{array}{l}735.2^{* * *} \\
{[531.3-1017.2]}\end{array}$ & $\begin{array}{l}434.1^{* * *} \\
{[312.2-603.7]}\end{array}$ & $\begin{array}{l}676.5^{* * *} \\
{[483.5-946.4]}\end{array}$ & $\begin{array}{l}631.2^{* * *} \\
{[446.5-892.2]}\end{array}$ \\
\hline Fold increase & 7.1 & 6.1 & 7.2 & 7.4 & 6.5 & 5.1 & 4.9 & 5.9 \\
\hline \multicolumn{9}{|c|}{ Vaxigrip vaccine $2012^{\mathrm{a}}$} \\
\hline Day $0(n=50)$ & $\begin{array}{l}130.0 \\
{[86.3-195.7]}\end{array}$ & $\begin{array}{l}108.5 \\
{[69.7-169.0]}\end{array}$ & $\begin{array}{l}130.0 \\
{[86.0-196.4]}\end{array}$ & $\begin{array}{l}130.0 \\
{[87.8-192.4]}\end{array}$ & $\begin{array}{l}145.2 \\
{[94.2-223.7]}\end{array}$ & $\begin{array}{l}97.1 \\
{[65.5-144.0]}\end{array}$ & $\begin{array}{l}145.2 \\
{[99.9-211.1]}\end{array}$ & $\begin{array}{l}137.4 \\
{[91.6-206.1]}\end{array}$ \\
\hline Day $21(n=50)$ & $\begin{array}{l}315.6^{*} \\
{[226.3-440.2]}\end{array}$ & $\begin{array}{l}307.0^{* *} \\
{[216.3-435.7]}\end{array}$ & $\begin{array}{l}338.2^{* *} \\
{[239.1-478.5]}\end{array}$ & $\begin{array}{l}333.6^{* *} \\
{[238.7-466.3]}\end{array}$ & $\begin{array}{l}388.5^{* *} \\
{[273.4-552.2]}\end{array}$ & $\begin{array}{l}229.4^{*} \\
{[167.7-313.9]}\end{array}$ & $\begin{array}{l}343.0^{* *} \\
{[251.9-467.0]}\end{array}$ & $\begin{array}{l}343.0^{* *} \\
{[249.5-471.5]}\end{array}$ \\
\hline Fold increase & 2.4 & 2.8 & 2.6 & 2.6 & 2.7 & 2.4 & 2.4 & 2.5 \\
\hline
\end{tabular}

The significance of differences (increase) between day 0 and day 21 geometric mean titres ${ }^{*} \mathrm{p}<0.01^{* *} \mathrm{p}<0.001^{* * *} \mathrm{p}<0.0001$.

\# One dose of non-adjuvanted trivalent seasonal influenza vaccine Fluarix ${ }^{\circledR}$ produced by GSK Biologicals was given in 2010.

${ }^{a}$ One dose of non-adjuvanted trivalent seasonal influenza vaccine Vaxigrip ${ }^{\circledR}$ produced by Sanofi Pasteur was given in 2012.

\section{Discussion}

The first influenza pandemic of the 21st century was caused by a novel reassortant H1N1 swine influenza virus with gene segments originating from avian, human and swine viruses [33]. Since the 2009 pandemic, influenza A(H1N1)pdm09 strains have continued to circulate in humans causing seasonal influenza epidemics. A (H1N1)pdm09 viruses have also succeeded in crossing the species barrier, and novel reassortant viruses with internal genes of $A$ (H1N1)pdm09 found in pigs may pose a threat to public health [34].

Antigenic sites of the HA molecule in H1N1 viruses have been identified which include the epitopes $\mathrm{Sa}, \mathrm{Sb}, \mathrm{Ca} 1, \mathrm{Ca} 2$ and $\mathrm{Cb}$ on the surface of the globular head of the molecule (Fig. 2) [35,36]. During the evolution, $\mathrm{A}(\mathrm{H} 1 \mathrm{~N} 1) \mathrm{pdm} 09$ viruses have carried more HA point mutations in the stem region than in antigenic sites [1]. A substitution E224A and others located in or in the vicinity of amino acid 151-159 surface loop have caused antigenic changes that can be detected in HI assays [37]. Reduced HI titres were also reported with amino acid changes N125D and N156K in the Sa epitope [26]. The yearly mutation rate at amino acid level has been estimated to be approximately $1.5 \%$ for the HA1 and $1.1 \%$ for the NA molecule [25].

The $A(H 1 N 1)$ viral component (A/California/07/2009) of seasonal influenza vaccines remained the same for several years, from
2010-2011 to 2016-2017, which enabled us to compare the immunogenicity of different vaccine preparations as well as to analyse the cross-reactivity of seasonal influenza vaccine-induced immunity against a wide variety of epidemic A(H1N1)pdm09 virus strains. We also compared the performance of the traditional HI assay and optimized the ELISA-based MN test analyzing vaccineinduced responses. In general, the levels of anti-influenza antibodies detected by the $\mathrm{HI}$ and MN assays correlated very well with each other, strongly suggesting that both assays measure similar types of anti-influenza antibodies. In other studies a good correlation has been shown between $\mathrm{HI}$ and MN assays, and also high sensitivity and specificity of MN for A/California/07/2009 vaccine virus induced antibody responses [38].

In accordance with previous observations [5], we found that MN titres tend to be higher than those obtained in the HI test. The HI titre of 40 corresponded to a MN titre of 160 . However, the data on the protective value of MN antibody titres against influenza varies considerably depending on the method and viruses used in the assays $[8,9,39]$.

The GMTs elicited by the 2010 Fluarix vaccination appeared to be higher than those seen after the 2012 Vaxigrip vaccination. The comparison of vaccine-induced antibody levels is difficult, since the vaccines were given in separate clinical trials. Moreover, the immune status of the vaccinees differed to some extent when the vaccines were administered in 2010 and 2012. Most of the par- 


\section{A}

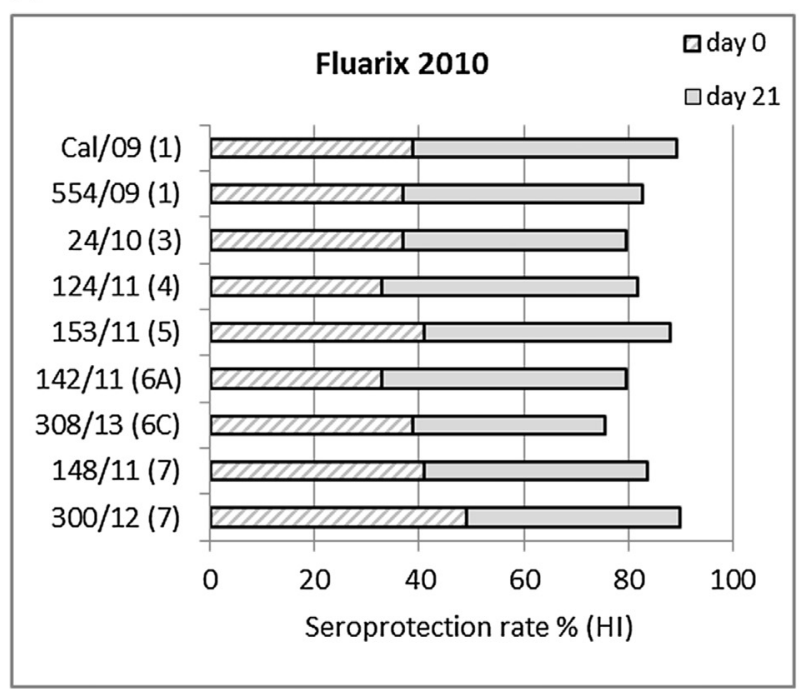

B

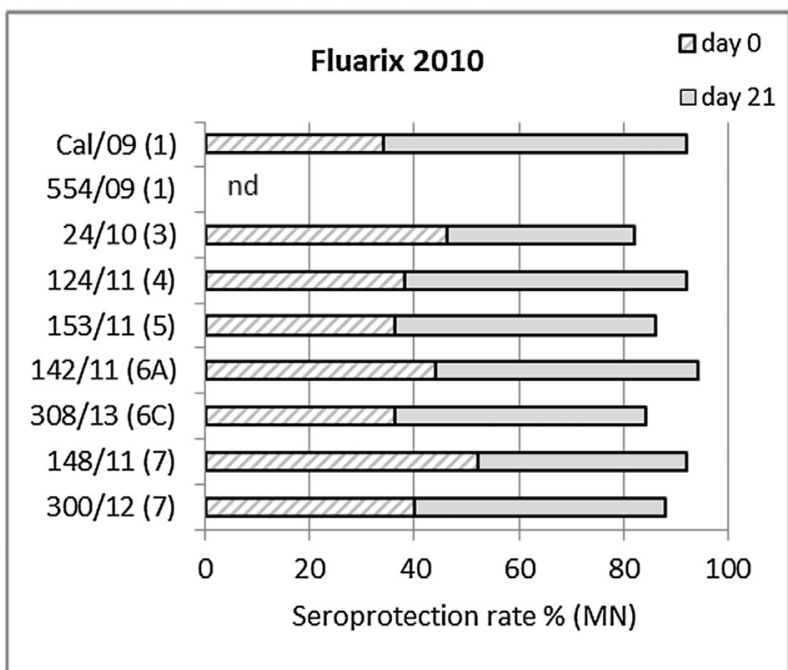

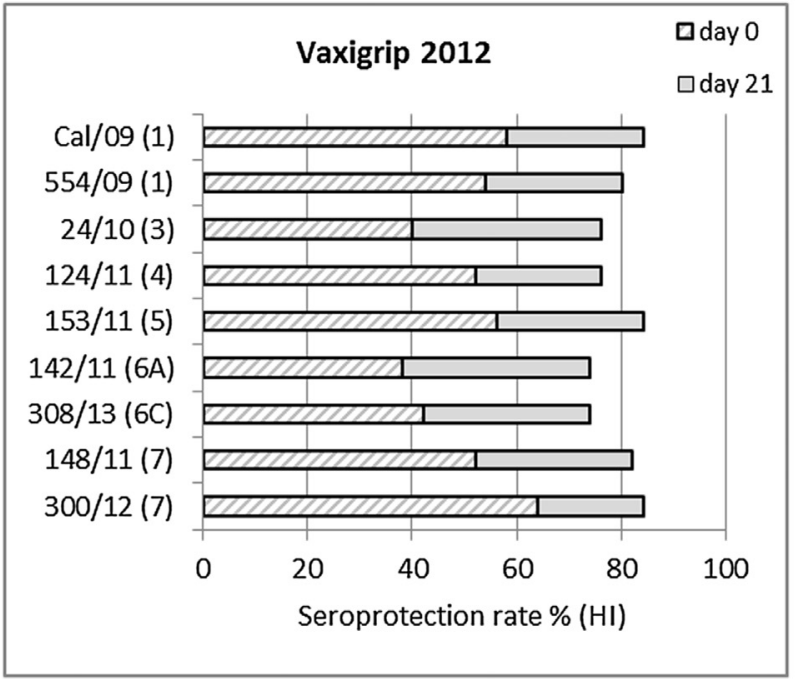

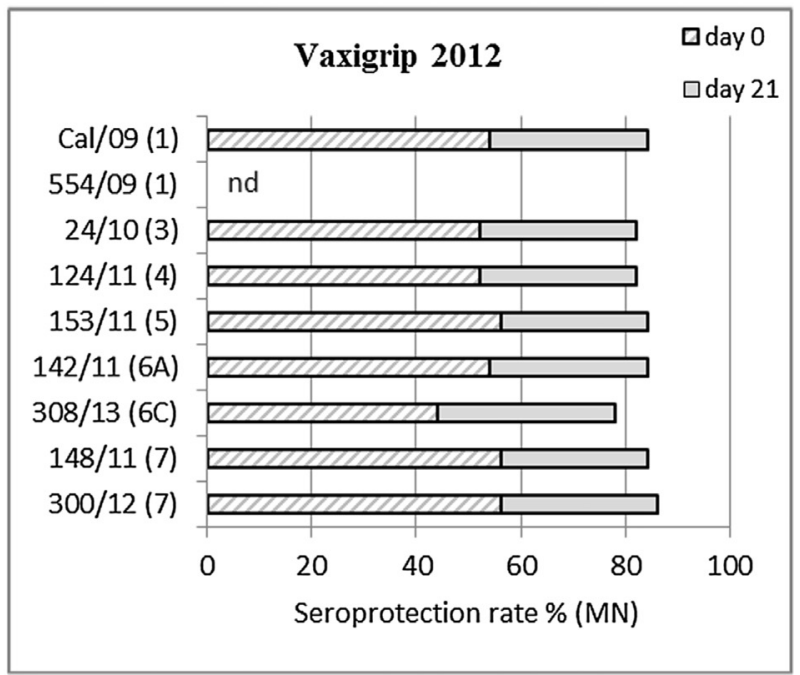

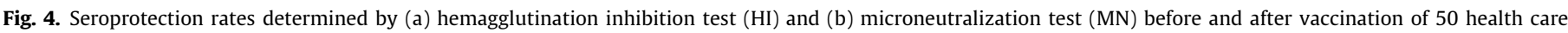

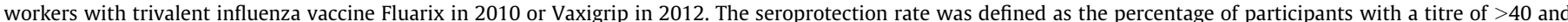

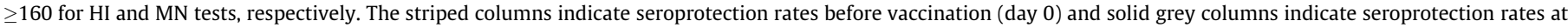
three weeks after vaccination (day 21). nd: not done (due to reduced amount of sera).

Table 3

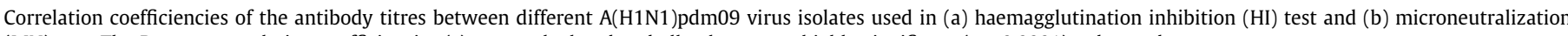
$(\mathrm{MN})$ test. The Pearson correlation coefficiencies $(r)$ were calculated and all values were highly significant $(p<0.0001)$. nd: not done.

\begin{tabular}{|c|c|c|c|c|c|c|c|c|}
\hline A & & & & & & & & \\
\hline Genetic group & 1 & 3 & 4 & 5 & $6 \mathrm{~A}$ & $6 C$ & 7 & 7 \\
\hline Virus strain & $554 / 09$ & $24 / 10$ & $124 / 11$ & $153 / 11$ & $142 / 11$ & $308 / 13$ & $148 / 11$ & $300 / 12$ \\
\hline A/California/7/2009 & 0.88 & 0.71 & 0.74 & 0.74 & 0.71 & 0.63 & 0.68 & 0.70 \\
\hline A/Finland/554/2009 & & 0.76 & 0.85 & 0.78 & 0.78 & 0.68 & 0.76 & 0.71 \\
\hline A/Finland/24/2010 & & & 0.80 & 0.91 & 0.98 & 0.71 & 0.94 & 0.85 \\
\hline A/Finland/124/2011 & & & & 0.87 & 0.82 & 0.86 & 0.83 & 0.87 \\
\hline A/Finland/153/2011 & & & & & 0.91 & 0.82 & 0.93 & 0.92 \\
\hline A/Finland/142/2011 & & & & & & 0.69 & 0.95 & 0.84 \\
\hline A/Finland/308/2013 & & & & & & & 0.72 & 0.83 \\
\hline A/Finland/148/2011 & & & & & & & & 0.84 \\
\hline A/Finland/300/2012 & & & & & & & & \\
\hline
\end{tabular}


Table 3 (continued)

\begin{tabular}{|c|c|c|c|c|c|c|c|c|}
\hline \multicolumn{9}{|l|}{ B } \\
\hline Genetic group & 1 & 3 & 4 & 5 & $6 \mathrm{~A}$ & $6 C$ & 7 & 7 \\
\hline Virus strain & $554 / 09$ & $24 / 10$ & $124 / 11$ & $153 / 11$ & $142 / 11$ & $308 / 13$ & $148 / 11$ & $300 / 12$ \\
\hline A/California/7/2009 & nd & 0.86 & 0.81 & 0.86 & 0.88 & 0.84 & 0.88 & 0.89 \\
\hline A/Finland/554/2009 & & nd & nd & nd & nd & nd & nd & nd \\
\hline A/Finland/24/2010 & & & 0.67 & 0.86 & 0.84 & 0.84 & 0.85 & 0.88 \\
\hline A/Finland/124/2011 & & & & 0.78 & 0.85 & 0.71 & 0.78 & 0.78 \\
\hline A/Finland/153/2011 & & & & & 0.89 & 0.86 & 0.91 & 0.91 \\
\hline A/Finland/142/2011 & & & & & & 0.81 & 0.87 & 0.88 \\
\hline A/Finland/308/2013 & & & & & & & 0.86 & 0.87 \\
\hline A/Finland/148/2011 & & & & & & & & 0.96 \\
\hline A/Finland/300/2012 & & & & & & & & \\
\hline
\end{tabular}

HI test
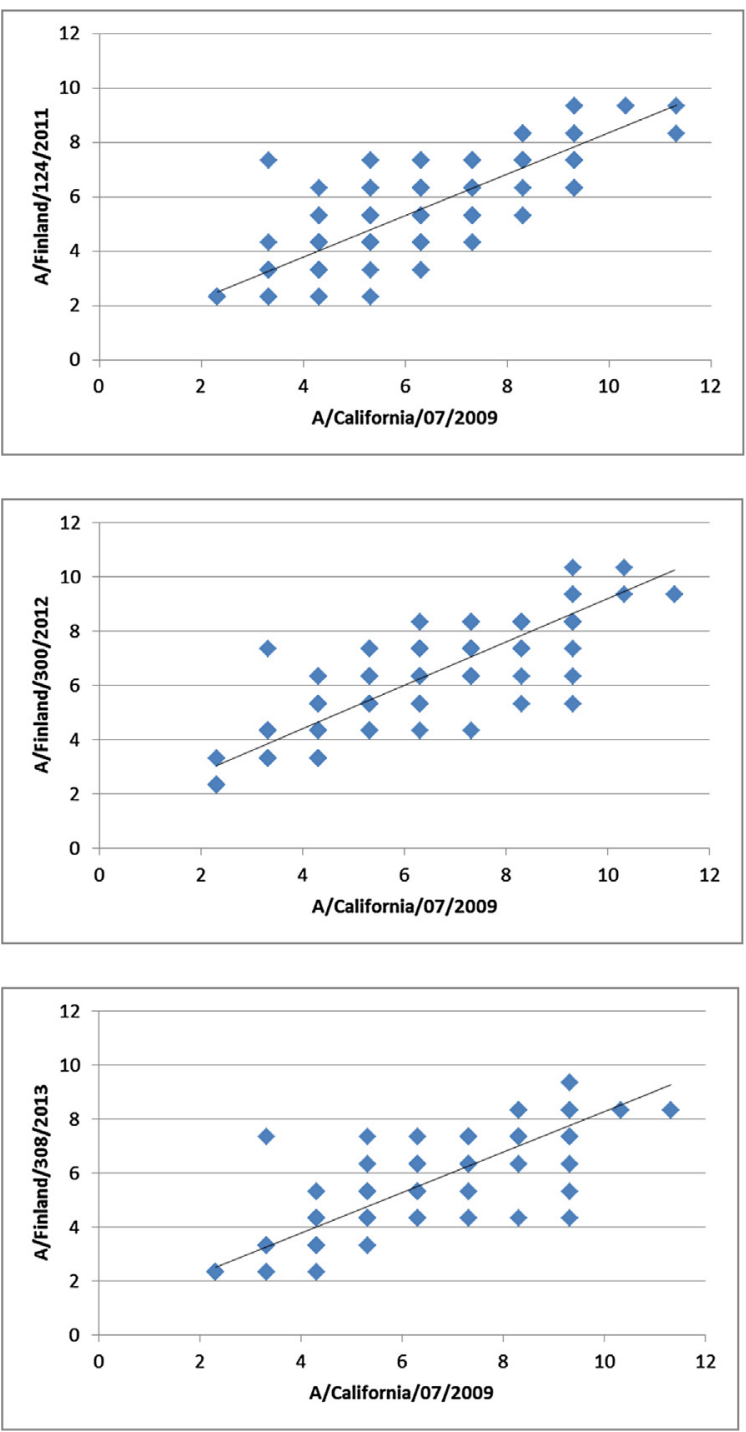

MN test
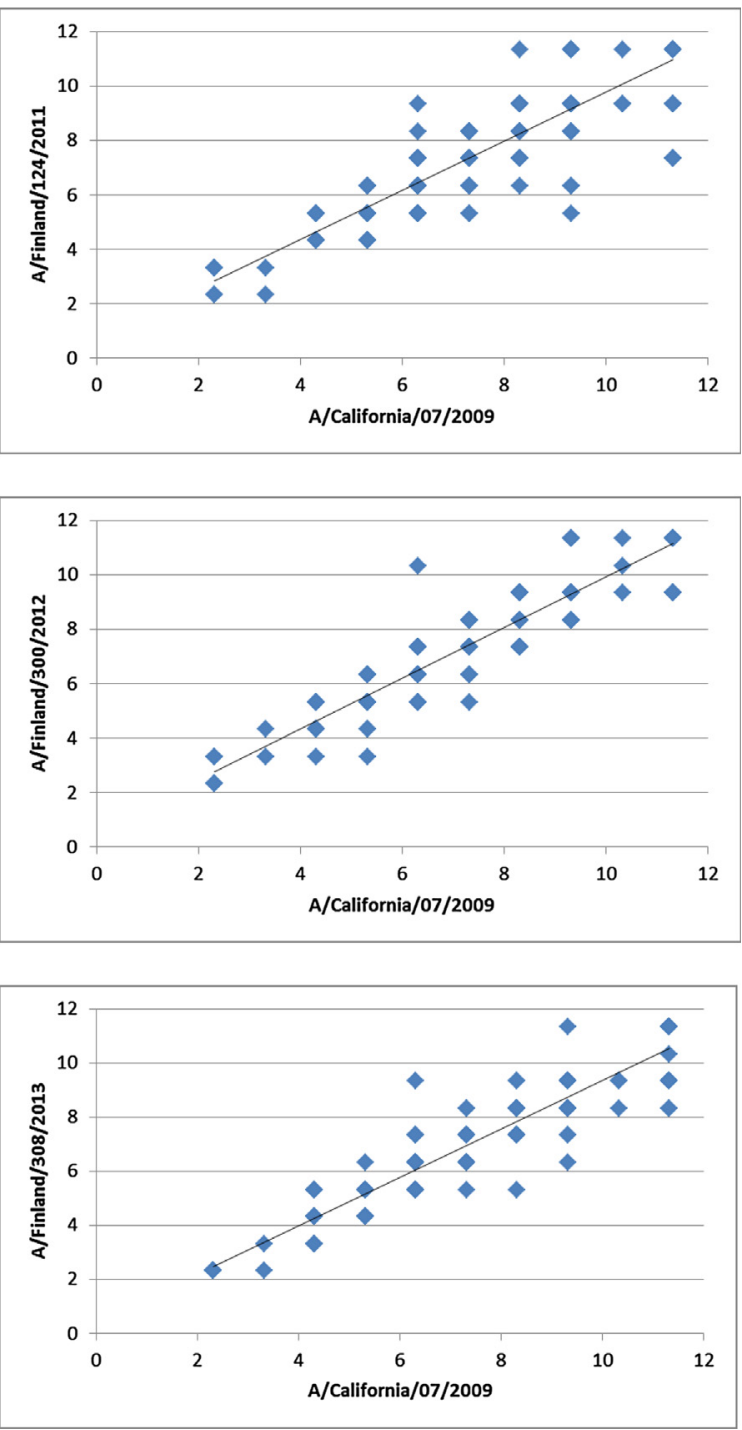

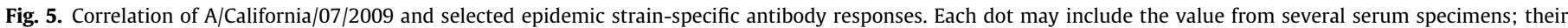
number totals $190-200$ in each panel.

ticipants in the Fluarix trial in 2010 had been given the vaccine Pandemrix only one year before the seasonal vaccination. Previous Pandemrix vaccination has been shown to strongly boost antibody responses against $A(\mathrm{H} 1 \mathrm{~N} 1)$ pdm09 viruses [40].

A total of 23 volunteers were the same in 2010 and 2012 trials, thus their immunization history was not similar during the two time periods: in 2012 most of the volunteers had an additional history of receiving vaccinations in 2010 and 2011. Indeed, albeit not statistically significant, we saw a tendency of somewhat higher pre-existing anti-H1N1pdm09 antibody levels and higher seroprotection rates in 2012 than in 2010. This may be due, not only to a history of sequential vaccinations among the study population, but 
in some cases, also to natural infections caused by A(H1N1)pdm09 viruses. Three weeks after vaccination with either one of the vaccines the GMT values increased significantly against all studied viruses. No significant differences between different virusspecific responses were found. Both seasonal influenza virus vaccines induced adequately high antibody levels that showed very good cross-reactivity against all analysed circulating wild type A (H1N1)pdm09 virus from different genetic groups. Accordingly, repeated annual vaccinations have been shown to be beneficial to HCWs promoting antibody avidity maturation against $\mathrm{A} /$ California/07/2009-like vaccine virus [13].

As measured by the MN test, correlation coefficiencies of the antibody titres between the A/California/07/2009 vaccine virus and epidemic $\mathrm{A}(\mathrm{H} 1 \mathrm{~N} 1)$ pdm09 viruses were somewhat higher as compared to the results obtained by the HI test. As the MN assay provides the detection of a wider range of antibodies than the HI test, the MN test is likely more sensitive in identifying antigenic similarities or differences between the viruses [5]. Although MN test is more laborious to conduct than the HI test, the MN test offers greater specificity, sensitivity and probably also better correlation to protection. Therefore, it should be favored in analyses of vaccine (and infection)-induced anti-influenza immunity. Presently, the HI assay fails to efficiently characterize $A(H 3 N 2)$ viruses due to either the variable agglutination of red blood cells from guinea pig, turkey and humans or the loss of the ability of viruses to agglutinate any of these cells [41]. The MN test may also be a more reliable method than the $\mathrm{HI}$ test in analysing vaccine- or natural infection-induced immunity against influenza viruses of various types, including the recently emerged $\mathrm{H} 3 \mathrm{~N} 2$ viruses.

Within a potential N-linked glycosylation site (160-162), the substitution K160N located in the antigenic site Sa of the A/Finland/300/2012 strain did not changed the antigenic profile compared to the A/California/07/2009 vaccine virus. Albeit we saw only limited antigenic variation in the responses against different genetic group viruses there was a tendency for the correlation coefficient to be higher between the viruses that were genetically and structurally more closely related to the vaccine virus and to each other.

In Finland, influenza $\mathrm{A}(\mathrm{H} 1 \mathrm{~N} 1) \mathrm{pdm} 09$ viruses predominated during the influenza seasons 2009-2010 [42], 2012-2013, 2013-2014 and 2015-2016 [43-45]. Our results indicate that the A/California/07/2009 vaccine virus induced antibodies with high cross-reactive potential, which likely provided good crossprotection against epidemic $\mathrm{A}(\mathrm{H} 1 \mathrm{~N} 1)$ pdm09 viruses during the influenza seasons 2010-2011 and 2012-2013. We have also shown that the A/California/07/2009 vaccine induced high seroprotection rates against a Finnish epidemic genetic group $6 \mathrm{~B}$ virus that was isolated in 2014 [46].

During the influenza season 2015-2016 two sub-clades within the $6 \mathrm{~B}$ clade emerged: $6 \mathrm{~B} .1$ and $6 \mathrm{~B} .2$. $\mathrm{HI}$ and virus neutralization assays using ferret antisera indicated that almost all the $A(H 1 N 1)$ pdm09 viruses were antigenically similar and closely related to the vaccine virus A/California/07/2009 [4]. The A/California/07/2009 vaccine strain was changed to A/Michigan/45/2015 and A/Brisbane/02/2018 strains for the 2017 southern and 20192020 northern hemisphere vaccines, respectively $[47,48]$. Both changes were based on immunogenicity analyses in humans rather than experimental data obtained in ferrets. HI assays with ferret antisera indicated that almost all recent $\mathrm{A}(\mathrm{H} 1 \mathrm{~N} 1) \mathrm{pdm} 09$ viruses were antigenically indistinguishable from the vaccine virus yet some of the epidemic viruses were poorly inhibited by some post-vaccination human sera.

Our study has certain limitations. As the number of HCWs participating was no larger than 50 and all age groups were not covered, the results do not necessarily apply to children or elderly individuals. Vaccine effectiveness in general remains lower among the elderly than among children and adults [49]. The results obtained in the two vaccination trials are not comparable as such, since the vaccines were not administered during the same year and the immune history of the vaccinees were likely quite different. Indeed, it is desirable that future studies would not only explore responses to the vaccine strains but would also compare different (seasonal) influenza vaccines for their immunogenicity and protective efficacy in the same clinical trial. However, it should be pointed out that both vaccines induced strong homologous and heterologous antibody responses against multiple $\mathrm{A}(\mathrm{H} 1 \mathrm{~N} 1)$ pdm09 viruses with very high theoretical seroprotection rates.

In the present study we optimized and used an MN assay together with a traditional HI assay to investigate antibody levels after seasonal influenza virus vaccinations. We demonstrated high rates of neutralizing antibodies against different circulating genetic groups of influenza $\mathrm{A}(\mathrm{H} 1 \mathrm{~N} 1)$ pdm09 viruses three weeks after seasonal influenza vaccinations. The results suggest strong vaccine-induced protection against circulating $\mathrm{A}(\mathrm{H} 1 \mathrm{~N} 1) \mathrm{pdm} 09$ viruses isolated in Finland between the years 2009 and 2013. In addition to protecting the staff themselves against influenza, vaccination of HCWs fulfills an important task of preventing the spread of influenza among the vulnerable patient groups.

\section{Acknowledgements}

We would like to thank all the volunteers who took part in this study. In addition, we thank Riitta Santanen, Minna Haanpää and Outi Rautio for their expert technical assistance and Tarja Silvasti for help with the recruitment process. The WHO Collaborating Centre at the National Institute for Medical Research, London, UK, is acknowledged for providing the A/California/07/2009 vaccine virus used in the $\mathrm{HI}$ and $\mathrm{MN}$ tests.

We gratefully acknowledge the authors and their respective laboratories, who analysed and submitted the sequences to GISAID's EpiFlu ${ }^{\mathrm{TM}}$ Database. All submitting laboratories may be contacted directly via the GISAID website www.gisaid.org.

\section{Authors' contributions}

All authors attest they meet the ICMJE criteria for authorship. $\mathrm{AH}$ performed $\mathrm{MN}$ tests, the serological data analysis and wrote the manuscript. NI carried out the genetic characterizations and the molecular models. NI, CSK and IJ also participated in the writing of the manuscript. AK, VJA, ER and IJ were involved in the design of TIV vaccination study and sera collections. All authors have read and approved the final version of the manuscript.

\section{Ethics statement}

The samples obtained were part of two studies conducted at the National Institute for Health and Welfare (THL) and HelsinkiUusimaa Health District. Written informed consent was obtained from all participants. The study protocols and consents were approved by the Ethics Committee of the Department of Medicine, Helsinki University Hospital (Permissions 382/E5/07 §48/2008 and 298/13/00/12) and received an European Union clinical trials database code of EudraCT 2010-023313-57 and 2012-003727-38, respectively..

\section{Role of the funding source}

The study was supported by funds from the National Institute for Health and Welfare (THL) and the Ministry of Social Affairs and Health. The funding organization had no role in the study 
design, data collection and analysis, decision to publish or preparation of the manuscript.

\section{Declaration of interest}

The authors' have nothing to disclose.

\section{Appendix A. Supplementary material}

Supplementary data to this article can be found online at https://doi.org/10.1016/j.vaccine.2019.03.078.

\section{References}

[1] Wedde M, Biere B, Wolff T, Schweiger B. Evolution of the hemagglutinin expressed by human influenza $\mathrm{A}(\mathrm{H} 1 \mathrm{~N} 1) \mathrm{pdm} 09$ and $\mathrm{A}(\mathrm{H} 3 \mathrm{~N} 2)$ viruses circulating between 2008-2009 and 2013-2014 in Germany. Int J Med Microbiol 2015 Aug 21. https://doi.org/10.1016/i.iimm.2015.08.030.

[2] World Health Organization. Review of the 2017-2018 influenza season in the northern hemisphere. World Health Organization. 2018 August 24,:429-44. https://www.who.int/wer/2018/wer9334

[3] Barr IG, Russell C, Besselaar TG, Cox NJ, Daniels RS, Donis R, et al. WHO recommendations for the viruses used in the 2013-2014 Northern Hemisphere influenza vaccine: epidemiology, antigenic and genetic characteristics of influenza $A(\mathrm{H} 1 \mathrm{~N} 1)$ pdm09, $\mathrm{A}(\mathrm{H} 3 \mathrm{~N} 2)$ and $B$ influenza viruses collected from October 2012 to January 2013. Vaccine 2014 Aug 20;32 (37):4713-25. https://doi.org/10.1016/i.vaccine.2014.02.014.

[4] World Health Organization. Recommended composition of influenza virus vaccines for use in the 2016-2017 northern hemisphere influenza season World Health Organization. 2016 Feb 25. https://www.who.int/ influenza/vaccines/virus/recommendations/2016_17_north

[5] Lin Y, Gu Y, Wharton SA, Whittaker L, Gregory V, Li X, et al. Optimisation of a micro-neutralisation assay and its application in antigenic characterisation of influenza viruses. Influenza Other Respir Viruses 2015 Jun 13. https://doi.org/ 10.1111/irv.12333.

[6] de Jong JC, Palache AM, Beyer WE, Rimmelzwaan GF, Boon AC, Osterhaus AD. Haemagglutination-inhibiting antibody to influenza virus. Dev Biol (Basel) 2003;115:63-73.

[7] Truelove S, Zhu H, Lessler J, Riley S, Read JM, Wang S, et al. A comparison of hemagglutination inhibition and neutralization assays for characterizing immunity to seasonal influenza A. Influenza Other Respir Viruses 2016 Nov;10(6):518-24. https://doi.org/10.1111/irv.12408.

[8] Verschoor CP, Singh P, Russell ML, Bowdish DM, Brewer A, Cyr L, et al. Microneutralization assay titres correlate with protection against seasonal influenza H1N1 and H3N2 in children. PLoS One 2015 Jun 24;10(6):. https:// doi.org/10.1371/iournal.pone.0131531e0131531.

[9] Grund S, Adams O, Wahlisch S, Schweiger B. Comparison of hemagglutination inhibition assay, an ELISA-based micro-neutralization assay and colorimetric microneutralization assay to detect antibody responses to vaccination against influenza A H1N1 2009 virus. J Virol Methods 2011 Feb;171(2):369-73. https://doi.org/10.1016/j.jviromet.2010.11.024.

[10] Hancock K, Veguilla V, Lu X, Zhong W, Butler EN, Sun H, et al. Cross-reactive antibody responses to the 2009 pandemic H1N1 influenza virus. N Engl J Med 2009 Nov 12;361(20):1945-52. https://doi.org/10.1056/NEJMoa0906453.

[11] Laurie KL, Engelhardt OG, Wood J, Heath A, Katz JM, Peiris M, et al. International laboratory comparison of influenza microneutralization assays for $\mathrm{A}(\mathrm{H} 1 \mathrm{~N} 1)$ pdm09, $\mathrm{A}(\mathrm{H} 3 \mathrm{~N} 2)$, and $\mathrm{A}(\mathrm{H} 5 \mathrm{~N} 1)$ influenza viruses by CONSISE. Clin Vaccine Immunol 2015 Aug;22(8):957-64. https://doi.org/10.1128/ CVI.00278-15.

[12] Stephenson I, Heath A, Major D, Newman RW, Hoschler K, Junzi W, et al. Reproducibility of serologic assays for influenza virus A (H5N1). Emerg Infect Dis 2009 Aug 1;15(8):1250-9. https://doi.org/10.3201/eid1508.081754.

[13] Eidem S, Tete SM, Jul-Larsen A, Hoschler K, Montomoli E, Brokstad KA, et al. Persistence and avidity maturation of antibodies to $\mathrm{A}(\mathrm{H} 1 \mathrm{~N} 1) \mathrm{pdm} 09$ in healthcare workers following repeated annual vaccinations. Vaccine 2015 Aug 7;33(33):4146-54. https://doi.org/10.1016/j.vaccine.2015.05.081.

[14] Gaglani M, Spencer S, Ball S, Song J, Naleway A, Henkle E, et al. Antibody response to influenza $\mathrm{A}(\mathrm{H} 1 \mathrm{~N} 1)$ pdm09 among healthcare personnel receiving trivalent inactivated vaccine: effect of prior monovalent inactivated vaccine. J Infect Dis 2014 Jun 1;209(11):1705-14. https://doi.org/10.1093/infdis/iit825.

[15] Lin SY, Wu ET, Lin CH, Shyu MK, Lee CN. The safety and immunogenicity of trivalent inactivated influenza vaccination: a study of maternal-cord blood pairs in Taiwan. PLoS One 2013 Jun 6;8(6): https://doi.org/10.1371/journal pone.0062983e62983.

[16] Tinoco JC, Pavia-Ruz N, Cruz-Valdez A, Aranza Doniz C, Chandrasekaran V, Dewe $W$, et al. Immunogenicity, reactogenicity, and safety of inactivated quadrivalent influenza vaccine candidate versus inactivated trivalent influenza vaccine in healthy adults aged $>18$ years: a phase III, randomized trial. Vaccine 2014 Mar 14;32(13):1480-7. https://doi.org/10.1016/ j.vaccine.2014.01.022.
[17] Jain VK, Rivera L, Zaman K, Espos Jr RA, Sirivichayakul C, Quiambao BP, et al. Vaccine for prevention of mild and moderate-to-severe influenza in children. N Engl J Med 2013 Dec 26;369(26):2481-91. https://doi.org/10.1056/ NEIMoa 1215817

[18] Domachowske JB, Pankow-Culot H, Bautista M, Feng Y, Claeys C, Peeters M, et al. A randomized trial of candidate inactivated quadrivalent influenza vaccine versus trivalent influenza vaccines in children aged 3-17 years. J Infect Dis 2013 Jun 15;207(12):1878-87. https://doi.org/10.1093/infdis/jit091.

[19] Langley JM, Scheifele DW, Quach C, Vanderkooi OG, Ward B, McNeil S, et al. Safety and immunogenicity of 2010-2011 H1N12009-containing trivalent inactivated influenza vaccine in children 12-59 months of age previously given AS03-adjuvanted H1N12009 pandemic vaccine: a PHAC/CIHR Influenza Research Network (PCIRN) study. Vaccine 2012 May 14;30(23):3389-94. https://doi.org/10.1016/j.vaccine.2012.03.046.

[20] Langley JM, Carmona Martinez A, Chatterjee A, Halperin SA, McNeil S, Reisinger KS, et al. Immunogenicity and safety of an inactivated quadrivalent influenza vaccine candidate: a phase III randomized controlled trial in children. J Infect Dis 2013 Aug 15;208(4):544-53. https://doi.org/10.1093/ infdis/iit263.

[21] Kieninger D, Sheldon E, Lin WY, Yu CJ, Bayas JM, Gabor JJ, et al. Immunogenicity, reactogenicity and safety of an inactivated quadrivalent influenza vaccine candidate versus inactivated trivalent influenza vaccine: a phase III, randomized trial in adults aged $>18$ years. BMC Infect Dis 2013 Jul;24(13):343. https://doi.org/10.1186/1471-2334-13-343.

[22] Bae EY, Choi UY, Kwon HJ, Jeong DC, Rhim JW, Ma SH, et al. Immunogenicity and safety of an inactivated trivalent split influenza virus vaccine in young children with recurrent wheezing. Clin Vaccine Immunol 2013 Jun;20 (6):811-7. https://doi.org/10.1128/CVI.00008-13.

[23] Matsumoto H, Ohfuji S, Watanabe K, Yamagami H, Fukushima W, Maeda K, et al. Booster influenza vaccination does not improve immune response in adult inflammatory bowel disease patients treated with immunosuppressives: a randomized controlled trial. J Gastroenterol 2015 Aug;50(8):876-86. https: I doi.org/10.1007/s00535-015-1042-7.

[24] Huijskens E, Rossen J, Mulder P, van Beek R, van Vugt H, Verbakel J, et al. Immunogenicity, boostability, and sustainability of the immune response after vaccination against Influenza A virus (H1N1) 2009 in a healthy population. Clin Vaccine Immunol 2011 Sep;18(9):1401-5. https://doi.org/10.1128/ CVI.05046-11.

[25] Ikonen N, Haanpaa M, Ronkko E, Lyytikainen O, Kuusi M, Ruutu P, et al. Genetic diversity of the 2009 pandemic influenza A(H1N1) viruses in Finland. PLoS One 2010 Oct 20;5(10):. https://doi.org/10.1371/journal.pone.0013329e13329.

[26] Strengell M, Ikonen N, Ziegler T, Julkunen I. Minor changes in the hemagglutinin of influenza $\mathrm{A}(\mathrm{H} 1 \mathrm{~N} 1) 2009$ virus alter its antigenic properties. PLoS One 2011;6(10): https://doi.org/10.1371/journal.pone.0025848e25848.

[27] Tamura K, Peterson D, Peterson N, Stecher G, Nei M, Kumar S. MEGA5: molecular evolutionary genetics analysis using maximum likelihood, evolutionary distance, and maximum parsimony methods. Mol Biol Evol 2011 Oct;28(10):2731-9. https://doi.org/10.1093/molbev/msr121.

[28] Saitou N, Nei M. The neighbor-joining method: a new method for reconstructing phylogenetic trees. Mol Biol Evol 1987 Jul;4(4):406-25. https://doi.org/10.1093/oxfordjournals.molbev.a040454.

[29] Tamura K, Nei M, Kumar S. Prospects for inferring very large phylogenies by using the neighbor-joining method. Proc Natl Acad Sci USA 2004 Jul 27;101 (30):11030-5. https://doi.org/10.1073/pnas.0404206101.

[30] Hillis DM, Allard MW, Miyamoto MM. Analysis of DNA sequence data: phylogenetic inference. Methods Enzymol 1993;224:456-87.

[31] Sayle RA, Milner-White EJ. RASMOL: biomolecular graphics for all. Trends Biochem Sci 1995 Sep;20(9):374.

[32] World Health Organization, Global influenza surveillance network. Manual for the laboratory diagnosis and virological surveillance of influenza. 2011. http:// whqlibdoc.who.int/publications/2011/9789241548090 eng.pdf

[33] Smith GJ, Vijaykrishna D, Bahl J, Lycett SJ, Worobey M, Pybus OG, et al. Origins and evolutionary genomics of the 2009 swine-origin H1N1 influenza A epidemic. Nature 2009 Jun 25;459(7250):1122-5. https://doi.org/ 10.1038 /nature08182.

[34] Kong W, Wang F, Dong B, Ou C, Meng D, Liu J, et al. Novel reassortant influenza viruses between pandemic (H1N1) 2009 and other influenza viruses pose a risk to public health. Microb Pathog 2015 Sep;4(89):62-72. https://doi.org/ 10.1016/i.micpath.2015.09.002.

[35] Gerhard W, Yewdell J, Frankel ME, Webster R. Antigenic structure of influenza virus haemagglutinin defined by hybridoma antibodies. Nature 1981 Apr 23:290(5808):713-7.

[36] Caton AJ, Brownlee GG, Yewdell JW, Gerhard W. The antigenic structure of the influenza virus A/PR/8/34 hemagglutinin (H1 subtype). Cell $1982 \mathrm{Dec} ; 31$ (2 Pt 1):417-27.

[37] Koel BF, Mogling R, Chutinimitkul S, Fraaij PL, Burke DF, van der Vliet S, et al. Identification of amino acid substitutions supporting antigenic change of $\mathrm{A}$ (H1N1)pdm09 viruses. J Virol 2015 Jan 21. https://doi.org/10.1128/JVI.02962$\underline{14}$.

[38] Tavakoli A, Rezaei F, Fatemi Nasab GS, Adjaminezhad-Fard F, Noroozbabaei Z, Mokhtari-Azad T. The comparison of sensitivity and specificity of ELISA-based microneutralization test with hemagglutination inhibition test to evaluate neutralizing antibody against influenza virus (H1N1). Iran J Public Health 2017 Dec;46(12):1690-6.

[39] Hsu JP, Zhao X, Chen MI, Cook AR, Lee V, Lim WY, et al. Rate of decline of antibody titers to pandemic influenza A (H1N1-2009) by hemagglutination 
inhibition and virus microneutralization assays in a cohort of seroconverting adults in Singapore. BMC Infect Dis 2014 Jul;28(14):414. https://doi.org/ 10.1186/1471-2334-14-414.

[40] Strengell M, Ikonen N, Ziegler T, Kantele A, Anttila VJ, Julkunen I. Antibody responses against influenza $\mathrm{A}(\mathrm{H} 1 \mathrm{~N} 1) \mathrm{pdm} 09$ virus after sequential vaccination with pandemic and seasonal influenza vaccines in Finnish healthcare professionals. Influenza Other Respir Viruses 2013 May;7(3):431-8. https:/l doi.org/10.1111/i.1750-2659.2012.00415.x.

[41] The Francis Crick Institute. Report prepared for the WHO annual consultation on the composition of influenza vaccines for the Southern Hemisphere 2019. 24-26 September 2018. WHO Collaborating Centre for Reference \& Research on Influenza, The Francis Crick Institute. 2018. https://www.crick.ac.uk/sites default/files/2018-10/September\%202018\%20interim\%20report_opt.pdf

[42] Lyytikainen O, Kuusi M, Snellman M, Virtanen M, Eskola J, Ronkko E, et al. Surveillance of influenza in Finland during the 2009 pandemic, 10 May 2009 to 8 March 2010. Euro Surveill. 2011 Jul 7;16(27).

[43] Ikonen N, Murtopuro S, Virtanen M, Lyytikäinen O. Influenssakausi Suomessa, viikot 40/2012-20/2013 - Seurantaraportti. 2013;Työpaperi : 2013_028. http://urn.fi/URN:ISBN:978-952-245-973-2

[44] Ikonen N, Murtopuro S, Virtanen M, Jokinen J, Baum U, Syrjänen R, et al. Influenssakausi Suomessa, viikot 40/2013-20/2014 - Seurantaraportti. 2014; Työpaperi: 2014_025. http://urn.fi/URN:ISBN:978-952-302-261-4
[45] Ikonen N, Murtopuro S, Haveri A, Virtanen M, Baum U, Nohynek H, et al Influenssakausi Suomessa, viikot 40/2015-20/2016: Seurantaraportti. 2016; Työpaperi : 2016_022. http://urn.fi/URN:ISBN:978-952-302-682-7

[46] Haveri A, Ikonen N, Julkunen I, Kantele A, Anttila V, Ruotsalainen E, et al. Reduced cross-protection against influenza $A(H 3 N 2)$ subgroup $3 \mathrm{C} .2 \mathrm{a}$ and 3C.3a viruses among Finnish healthcare workers vaccinated with 2013/14 seasonal influenza vaccine. Euro Surveill. 2015 Feb 5;20(5):21028.

[47] World Health Organization. Recommended composition of influenza virus vaccines for use in the 2017 southern hemisphere influenza season. World Health Organization. 2016 Sep 29. https://www.who.int/influenza/vaccines/ virus/recommendations/2017_south

[48] World Health Organization. Recommended composition of influenza virus vaccines for use in the 2019-2020 northern hemisphere influenza season World Health Organization. 2019 Feb 21. https://www.who.int/ influenza/vaccines/virus/recommendations/2019_20_north

[49] Cheng LW, Huang SW, Huang LM, Chang LY, Shao PL, Kiang D, et al Comparison of neutralizing and hemagglutination-inhibiting antibody responses for evaluating the seasonal influenza vaccine. J Virol Methods 2012 Jun;182(1-2):43-9. https://doi.org/10.1016/i.jviromet.2012.03.004. 